\title{
Public Relations Management Through Management By Objective
}

Lusy Tunik Muharlisiani, Endang Noerhartati, Karwanto Karwanto, Dina Chamidah, Nugrahini Susantinah Wisnujati, Herfa Maulina Dewi Soewardini, Mulono Apriyanto, Amrozi Khamidi, Riris Andriati, Dewi Fitriani, Fenita Purnama Sari Indah, Ahmad Thohirin, A Faizin, Muhammad Nuril Huda, Suyitno Suyitno, Siti Bariroh, Retno Indah Rahayu, Hermanoadi Hermanoadi, Mumayyizah Mumayyizah, Heni Sukrisno, M Chairul Basrun Umanailo

\begin{abstract}
Background research due to the high market demand toward ground transportation, rail priority particularly subject to subject to punctuality, speed and convenience, PT KAI to diversify its business by holding economy class, business executives to meet market needs. This research method using this qualitative study, Researchers used a interpretative paradigm. Interpretative paradigm aims to understand the meaning of behavior, symbols, and phenomena using purposive sampling. The technique of collecting the the data using interviews, documentation, and observation. The results of this study that the concept of management by objectives in PT KAI station Tulungagung items items, namely the implementation of the motivation for the achievement of common goals between leaders and subordinates to Obtain an opinion about the company's objectives and plans of cooperation, as well as Efforts to Achieve within a predetermined time together. Involve; every employee and manager to discuss, agree, autonomous binding assignment of responsibility, the implementation of the goals within the specified time together. Process and checking the implementation of the planning of the work carried out jointly between leaders and subordinates to discuss what has been what has not been achieved through progress review.
\end{abstract}

Keywords: public, relations, management, objectives, service

\section{INTRODUCTION}

In the highly competitive business world, success can be achieved by companies that realize that the consumer is the most important venture capital. Quality services to consumers by companies will impact the growth of consumer confidence to the company. Trust will be formed if the internal management of a company is Able to direct and produce a reliable human resources to the roomates has high capability to provide the best service. Successful management in managing the company can be seen from the extents to the

- Lusy Tunik Muharlisiani, Universitas Wijaya Kusuma Surabaya, Indonesia. Email: lusytm_fbs@uwks.ac.id

- Endang Noerhartati, Universitas Wijaya Kusuma Surabaya, Indonesia. Email: endang_noer@uwks.ac.id

- Karwanto, Karwanto, Universitas Negeri Surabaya, Indonesia. Email: karwanto@unesa.ac.id

- Dina Chamidah, Universitas Wijaya Kusuma Surabaya, Indonesia. Email: dinachamidah_fbs@uwks.ac.id

- Nugrahini Susantinah Wisnujati, Universitas Wijaya Kusuma Surabaya, Indonesia. Email:wisnujatinugrahini@uwks.ac.id

- Herfa Maulina Dewi Soewardini, Universitas Wijaya Kusuma Surabaya, Indonesia. Email: herfasoewardini_fbs@uwks.ac.id

- Mulono Apriyanto, Universitas Islam Indragiri. Indonesia. Email mulonoapriyanto71@gmail.com

- Amrozi Khamidi, Universitas Surabaya, Indonesia. Email: amrozikhamidi@unesa.ac.id

- Riris Andriati, Stikes Widya Dharma Husada Tangerang, Indonesia. Email ririsandriati@wdh.ac.id

- Dewi Fitriani, Stikes Widya Dharma Husada Tangerang, Indonesia. Email: dewifitriani@wdh.ac.id

- Fenita Purnama Sari Indah, Stikes Kharisma Persada, Indonesia. Email: fenita.purnama@masda.ac.id

- Ahmad Thohirin, Universitas Gresik, Indonesia. Email: sthohirin@yahoo.co.id

- A Faizin, Universitas Gresik, Indonesia. Email:vaiz.achmad@gmail.com

- Muhammad Nuril Huda, Universitas Islam Negeri Sunan Ampel Surabaya, Indonesia. Email: nuril.huda@uinsby.ac.id

- Suyitno Suyitno, Universitas Gresik, Indonesia. Email: onteause.ngalam@gmail.com

- Siti Bariroh, Universitas Gresik, Indonesia. Email: sitibariroh60@yahoo.com

- Retno Indah Rahayu, Universitas Gresik, Indonesia. Email: retnoindahrahayu@yahoo.co.id

- Hermanoadi Hermanoadi, Universitas Gresik, Indonesia. Email. hermanoadi1962@gmail.com

- Mumayyizah Mumayyizah, Universitas Gresik, Indonesia. Email: mayyiz2418@gmail.com

- Heni Sukrisno, Universitas Universitas Wijaya Kusuma Surabaya, Indonesia. Henisukrisnoffos@uwks.ac.id

M Chairul Basrun Umanailo, Department of Agricultural and Forestry, University of Iqra Buru, Maluku 97571, Indonesia. Email: chairulbasrun@gmail.com which the objectives of the company that has been set is Reached, therefore the management as the management company must Rely on the planning and control functions [1]. In the face of fierce competition in the field of transport and communications have led companies must have a strategy in order to have high long-term competitiveness in the face of global competition. Only companies that are flexible in meeting the needs of reviews their consumers who would be Able to survive and thrive in the global competition and sharp (Trapp). Flexibility is always market demands require the company is Able to produce products and services that meet the needs of its customers. Flexibility requires company management to continuous improvement benefits contained in the goods and services for the enterprise customer[2].

Ability to adapt quickly intervening intervening to any changes in consumer needs is key to success of companies from competition in order to become a leader in the competition in the market. One early effort right in this case is the planning, coordination and control adequately for the company related to the sales budget. With the planning, coordinating, and controlling the sales budget is expected the company will be Able to prepare better planning, coordination and control adequately for the company related to the sales budget[3]. With the planning, coordinating, and controlling the sales budget is expected the company will be Able to prepare better planning, coordination and control adequately for the company related to the sales budget. With the planning, coordinating, and controlling the sales budget is expected the company will be Able to prepare better planning [4]. PT Kereta Api Indonesia (KAI) is one company that is engaged in land freight transport that product services is a means of rail transport is Widely used Indonesian people, the event is one means of land freight transport, seeded and demand market of the transport service is very high. In order to survive in the competitive provision of land transportation services (Varma). PT. KAI should be Able to meet the needs of the market, in addition to the PT. KAI must have a means to achieve its goals, one of the roomates Management by 
Objective (MBO). This is done in order to achieve the desired maximum profit company[5]. Due to the high market demand toward ground transportation, rail priority particularly subject to subject to punctuality, speed and convenience.

\section{LITERATURE REVIEW}

\subsection{Strategy}

A series of activities that aim to achieve the goals and targets based on the present situation (situation). Strategy is the summary of the tactics to be used. According to Stephen Robbins defines that the strategy is the determination of the company's long-term goals and decide a course of action and to obtain the resources necessary to reach a destination. Strategic thinking include acts estimate or build the desired future goals, determine the forces that will help or will hinder the achievement of goals, and formulate a plan to achieve a desired state[6].

\subsection{Competitive Advantage}

The purpose of strategic and tactical development of the market is that companies are able to compete in every state, especially during the economic and political conditions that are less favorable. Therefore, the company must have a competitive advantage. According to Kohler (2005) notion of competitive advantage, namely an edge over competitors in getting to deliver greater customer value, through lower prices or by providing more benefits that correspond with higher pricing[7].

Companies competing in the same target market will always differ in purpose and its resources. There is a large-sized enterprise, some are small. There is also a lot of other resources funding difficulties. There is long-standing and more steady new and inexperienced. There were desperately seeking rapid growth in market share, others are looking for long-term profits. Companies may occupy a distinct competitive position in the market.

\subsection{Proses Strategic Planning}

Planning a business group that is considered effective. Where people have to know about achieving something as expected. Strategic planning is a work plan strategies to guide all actions of the company. Managerial processes to build and maintain compatibility between the resources and the organization and opportunities-opportunities.

Kotler (1999) state it that market-oriented strategic planning is managerial process to develop and maintain the skills and resources of interest in accordance with the organization's ever-changing market opportunities[8]. The purpose of strategic planning is to establish and enhance the business and the company's products that meet earnings targets and growth.

Strategic planning provides a framework for the activities of companies that can improve the responsiveness and the functioning of the company. Strategic planning helps managers develop a clear concept of the company. In addition, a strategic planning allows companies prepare themselves facing a rapidly changing environment activities. Other important advantages of strategic planning is to help managers see a chance that contain risks and opportunities that safe and choose between one of the opportunities that exist[9]. Possibility strategic planning also reduces errors and unpleasant surprise, because of careful study has been done on the goals, objectives and strategic

Target communication has never been separated from the orientation of effectiveness. To achieve the necessary communication effectiveness of certain operational strategies. And to get an idea of the communication strategy in advance authors provide an overview of understanding in relation to the communication strategy.

\section{METHOD}

This study will be conducted in a implemented a starting on January 18, 2019 until February 18, 2019 in PT. Kereta Api Indonesia operational area 7 Madiun tulungagung station Antasari prince road tulungagung Subdistrict of East Java Tulungagung 66212.

The author conducted in-depth interviews on public relations management strategy through Management by Objective (MBO) PT Kereta Api Indonesia operational area 7 Madiun Tulungagung station.

The main sources of the Data in this study are words and actions, the rest of the additional acre of data such as photo documentation, recordings and other similar writing. With regard to the data, the types can be divided into words and actions, written sources of the data, the photographs and statistics [10]. In this study the authors' of the techniques of data collection used in-depth interviews of observational activities directly related to informant research [11].

For the the data to the analysis, the authors use when the collection of the data takes place, and after the completion of the collection of the data in A Certain period. By analyzing the when collecting the data the writer can know firsthand the lack of the the of data that must be collected as well as the methods that must be Carried out next to get the a comprehensive, results [12]. By presenting the Data Researchers can work more quickly intervening intervening intervening and precisely in coding and decision making based on research focus. Presentation of the data is an integral part of qualitative research to the analysis of data. Presentation of the Data to the analysis as part of the reduction Is Also part of the Data to the analysis [13]. Presentation of the data in qualitative research in General i e matrices, graphs.

\section{Result}

PT Kereta Api (Persero) is a State-Owned Enterprises (SOEs) which is engaged in transport services transport of passengers and goods, negotiations, containers using the train as a means. Train itself for the first time introduced in Indonesia in the Dutch colonial era in 1864 by building a cross in Semarang[14], this time the railway company (Persero) has begun to develop with headquarters in Bandung.

On 17 June 1864 the Governor General Sloed Beele do first perjangkauan marks the start of railway in Indonesia, by placing a cross in Semarang (Kamijen). In accordance with a position in Indonesia when it was a colony, the motives of the establishment of the train moved from the State's interest 
invaders, namely; Motif economic/commercial which is sending crops in Indonesia to Semarang harbor. Political motives/Defense which is a reason and a very strong foundation.

Since the manufacture of rail traffic, further growth in Indonesia, especially in Java is getting noticed and expanded with the same motive. The growth of the railway has not only spearheaded by the Dutch government but also by the Dutch companies, for example in Java such as: SCS (Semarang Cirebon Stoom Maatschappi), SLS (Semarang Joana Stoom Train Maatschppi), KSM (Kediri Stoom Train My), MSM (Malang Stoom My Train. the stages of development of the Railways in general; Age of the Republic of Indonesia (Aug 17 1945-18 December 1948) was officially born September 1945 DKARI (Department of Railways of the Republic of Indonesia), based in Bandung. While at that time only includes Java for railway in North Sumatra stand alone. Endorsement Sovereignty January 1950 merger between DKARI with SSVS (Staats Spoorweg / Verenigf Spoorweg) which dominated the Dutch became the Republic of Indonesia DKARIS turned into DKA. State company in May 1963 turned into PNKA DKA (State Railway Company) pursuant to Act No. 22 of 1963. Ratification by the Bureau of Government Regulation No. 61/71, 15 September 1971 has been set changes PNKA a departmental agency status (Testament). General Company. By Regulation No. 57 of 1993, dated October 30, 1990 set changes in the status of departmental agency the Public Company Railways (PERUMKA) entered into force on 30 October 1990. Limited. By Regulation No. 19 of 1998 on the charge in the form of Perum to Persero.

Duties and Powers; to perform the duties and responsibilities of the Company was helped by 3 manager, file manager and document that the General in charge of the company archives of correspondence and other documents. File and Document Manager Asset Ownership is responsible for the administration of documents of ownership of assets (land, buildings, and suggestions lok, hoppers). File Manager and Legal Documents is responsible for the administration of other legal documents in the form of a Memorandum of Understanding (MoU), the contract or the presentation of the cooperation, agreements and other legal documents. File and Document Manager General was helped by four young staff, namely; Young staff correspondence and attitude that is responsible for the administration of correspondence and attitude. Young staff other corporate documents are responsible for the administration of records / documents of the company. Electronic Document Young staff responsible for the administration of documents with electronic systems. Young library staff responsible for the administration of a document library.

Latest Work Effort PT Kereta Api (Persero) always creates a program that annually changing according to the needs of its customers to increase the interest of consumer users of railway services. PT. Kereta Api (Persero) has a current work effort, which is running a program like the following:

Safety

PT Kereta Api trying to improve the safety of the passengers from year to year, so that consumers have more confidence and be a consumer phase PT service users. Kereta Api (Persero) Medan. When the PT. Kereta Api (Persero) Medan are working on fixing the railroad tracks along the track rail travel. Servicing every community, especially consumer service users PT Kereta Api (Persero) want good service and perfect.

Service

PT Kereta Api (Persero) also held a service improvement by educating employees to better understand the demand for passenger rail.

Convenience

Every activity or place, everyone in need of comfort, as well as the passengers on the train. So why, PT Kereta Api trying to improve comfort in each train, so that passengers use the services more spirit PT Kereta Api (Persero). Currently, PT Kereta Api is seeking to improve comfort by adding sanitary facilities in each train, such as providing trash cans, brooms and cleaning cloth every railway carriage and others.

On time

PT Kereta Api (Persero) was well aware that the occupants or users of services, very mengahrgai time. Then passengers expect any of their trip by train until the right time or according to a predetermined time. PT Kereta Api (Persero) also improve punctuality in departure and reduces the time stops at every station, so that the passengers can arrive at the destination on time.

Tulungagung Rejotangan station is a station class III / small street located Rejotangan Java Tulungagung subdistrict Rejotangan Timur.Stasiun located at an altitude of about -kira 116 meters above sea level is the most western active station in the operation area VII Madiuan cross Blitar - BangilKertosono, At this station there Daop Madiun.Stasiun VII is a little sign to the north on the highway TulungagungBlitar.Stasiun two routes with the first track as rail lurus. After this station before there Blitar Station Bendo station which has now been razed to the ground, the train service is Neat Doho Blitar goal Kertosono continued to Surabaya.

\section{Discussion}

Application of motivation for the achievement of common goals between leaders and subordinates to Obtain an opinion about the company's objectives and plans of cooperation, as well as Efforts to Achieve the Same Collectively predetermined time period [15]. How does application of motivation for the achievement of common goals between leaders and subordinates, it as submitted Tulungagung station head of the interview below: "By awarding bonuses or rewards for all employees if this common goal can be achieved. Besides, between leaders and subordinates always do open communication, leadership Provides direction to subordinates, and to conduct joint education and orientation exercises" (Interview, January 26, 2019).

From interviews the above in mind that with bonuses or rewards for all employees if this common goal can be achieved. Besides, between leaders and subordinates always do open communication, leadership Provides direction to subordinates, as well as joint training orientation [16][17]. Purpose company is the main thing that must be Achieved by the employees, so that management by objectives (MBO) is very Necessary role in the implementation of the motivation for common goal in Tulungagung station. Application of 
motivation with bonuses or awards to employees.

involve; every employee and manager to discuss, agree, autonomous binding assignment of responsibility, the implementation of the goals within the specified time Collectively same. Is the discussion leaders and employees in implementing the objectives of the company, it is as stated head of Tulungagung statisun the results of the interview below:

"Yes, it is meant that established cooperation between leaders and subordinates so that the ideals/destinations reached. At the same immediately company so that there is interaction between leaders and employees, so that employees felt Also in need in the achievement of corporate goals" (Interview, January 26, 2016).

From the interview above in mind that with the cooperation between leaders and subordinates so that the ideals / company goal to be Reached. At a time so there is interaction between leaders and employees, so that employees felt Also in need in achieving the goals of the company. The existence of cooperation between leaders and subordinates in Tulungagung station done to achieve a common goal or purpose of the company [18]. With the involvement of employees will Contribute or very big impact in the achievement of common goals through management by objectives (MBO) in Tulungagung station [19].

Process and checking the implementation of the planning of the work carried out jointly between leaders and subordinates to discuss what has been what has not been achieved through progress review whether the leadership and subordinates do the implementation work planning or progress review, it is like that delivered the station master Tulungagung from interviews below this:

"Yes, top-level manager always carry out planning the tentative program of work every week and divide tasks to subordinates[20]. Subordinates and Superiors always do a review, this is done for revising the deficiencies in regard to in order to achieve company goals more optimal" (interview, January 26, 2016).

From the interview above is known that upper level managers always carry out the planning of the program of work every week and divide tasks to subordinates [21]. Superiors and subordinates always do a review, this is done to revise deficiencies in regard to in order to Achieve company goals the roomates is more optimal. With the management by objectives (MBO) in Tulungagung station is known that the manager in a management always do the planning of work programs and always do the job evaluation each week. This is done so that the system work station can run with the maximum Tulungagung. MBO process in the management of public relations in an organization management through organizing techniques as follows:

It is known that a review of the work and is performed to Determine Whether the planning program that has been the Agreed-upon actually done or not and to what extent the program is running so that in case of obstacles or barriers that may Affect the common goal of Easily identifiable and Immediately find a way out, whether it is for long term or short term [22]. Re-defining the organization plans to do in every week / month to create the latest innovations from the review and revision of the previous program that has been completed on the run [23].

It is known that the results and accomplishments Achieved is a benchmark of the success of the planning of the work that's been made before, but it tight, while we strive to provide optimal service to customers, so we must be committed to it, so that customers feel satisfied.

It is known that the company wants to create a conducive working atmosphere, it is very important to do the work environment in order to produce a productive and innovative performance, so that the common goal of the company will be quickly intervening intervening Achieved. Clearly with the organizational structure illustrates the separation between the work activities with each other and how the relationship between activity and function in the limit. Described in the organizational structure the relationship of authority who reports to work at the station who. Tulungagung atmosphere is always in a state of an environment conducive for employment comfort play a huge role in the raise the labor productivity of employees.

The concept of management by objectives (MBO) at PT KAI station Tulungagung namely: Implementation of the motivation for the achievement of common goals between leaders and subordinates to Obtain an opinion about the company's objectives and plans of cooperation, as well as Efforts to Achieve within a predetermined time together, involve;; every employee and manager to discuss, agree, autonomous binding assignment of responsibility, the implementation of the goals within the specified time together. Process and checking the implementation of the planning of the work carried out jointly between leaders and subordinates to discuss what has been what has not been achieved through progress review[24]. Information is given openly and Cleary by the management company in an effort to effectively control and efficiency, and to facilitate precise control of decisions objectively. The scoring system is the ability to work, the two benchmark guidelines accomplishments or results that have been achieved in accordance with the standards and attention to every individual potential employees in an effort to identify reviews reviews their capacity to develop more advanced.

\section{CONCLUSION}

Proper planning of development cooperation in the $\mathrm{MBO}$ models, the roomates help each manager to be Able to overcome the weaknesses or deficiencies occurring saw in his leadership. Raising awareness and capability development of cooperation between leaders and subordinates. Increase and Utilize reviews their internal strength of personnel and resources of the company. Increasing motivation through a planning manager, screening, assessment and replacement work teams effectively and efficiently.

The importance of applying management by objectives (MBO) at the station Tulungagung is to Achieve effective management of the organization, in particular the implementation of the Management by objective (MBO) by the PR Whose meaning is to drive better management of activities in an integrated and coordinated functions between departments within an organization or with another 
Effectively purpose is the achievement of the effective functioning of management by objectives (MBO) is a major contribution to the development progress in the management of the regional operational PT.KAI 7 Madiun Tulungagung station.

\section{REFERENCES}

[1] L. Ang, "Community relationship management and social media," J. Database Mark. Cust. Strateg. Manag., 2011.

[2] A. E. Wise, "Book Reviews: Street-level Bureaucracy: Dilemmas of the Individual in Public Services," Educ. Eval. Policy Anal., 2009.

[3] K. Jones and J. Bartlett, "The strategic value of corporate social responsibility: a relationship management framework for public relations practice," Prism, 2009.

[4] A. R. Diers and J. Donohue, "Synchronizing crisis responses after a transgression: An analysis of BP's enacted crisis response to the Deepwater Horizon crisis in 2010," J. Commun. Manag., 2013.

[5] L. Rumkel, B. Sam, and M. C. B. Umanailo, "Village Head Partnership, Village Consultative Body and Customary Institution in Village Development," Int. J. Sci. Technol. Res., vol. 8, no. 8, pp. 1058-1063, 2019.

[6] N. L. Trapp, "Stakeholder involvement in CSR strategy-making? Clues from sixteen Danish companies," Public Relat. Rev., 2014.

[7] R. K. Yeo and M. Marquardt, "Think before you act: Organizing structures of action in technology-induced change," J. Organ. Chang. Manag., 2015.

[8] P. C. Verhoef, W. J. Reinartz, and M. Krafft, "Customer engagement as a new perspective in customer management," J. Serv. Res., 2010.

[9] A. Hasan Afandi and M. C. B. Umanailo, "Watudakon Citizens 'Social Conflict on Joker Toll Road Development in 2017 in Kesamben District, Jombang Regency," J. Soc. Sci. Res., vol. Special Is, no. 5, pp. 656-661, 2018.

[10] B. FitzPatrick, "Validity in qualitative health education research," Curr. Pharm. Teach. Learn., vol. 11, no. 2, pp. 211-217, Feb. 2019.

[11] J. A. Maxwell and L. E. Reybold, "Qualitative Research," in International Encyclopedia of the Social \& Behavioral Sciences: Second Edition, 2015.

[12] M. C. B. Umanailo, M. Yulisvestra, K. K. Oki, W. Mulyasari, and R. Ridwan, "The Thought of Emile Durkheim in the Contestation of Development in Indonesia," Int. J. Sci. Technol. Res., vol. 8, no. 8, 2019.

[13] S. Yusuf, M. C. B. Umanailo, R. N. Putri, D. Q. M. Ely, and D. Darma, "Village Institution Relations in the Utilization of Village Funds in Namlea District," Int. J. Sci. Technol. Res., vol. 8, no. 8, 2019.

[14] S. A. Hadighi, N. Sahebjamnia, I. Mahdavi, and M. Akbarpour Shirazi, "A framework for strategy formulation based on clustering approach: A case study in a corporate organization," KnowledgeBased Syst., 2013.

[15] M. C. B. Umanailo, R. Umanailo, R. Bugis, and A. T. Bon, "Empowerment Community in Buru Regency," in Proceedings of the International Conference on Industrial Engineering and Operations Management, 2019, pp. 2070-2075.
[16] T. Karp and T. I. T. Helg $\oslash$, "From Change Management to Change Leadership: Embracing Chaotic Change in Public Service Organizations," J. Chang. Manag., 2008.

[17] A. Assagaf et al., "Educational Political Policy," Int. J. Sci. Technol. Res., vol. 8, no. 9, 2019.

[18] M. D. Johnson, "Customer Satisfaction," in International Encyclopedia of the Social \& Behavioral Sciences: Second Edition, 2015

[19] F. Boncinelli, F. Bartolini, and L. Casini, "Structural factors of labour allocation for farm diversification activities," Land use policy, 2018.

[20] L. J. Buton et al., "The Effect of Nasa Liquid Organic Fertilizer Concentration and Planting Distance to Growth and Production of Beans," Int. J. Sci. Technol. Res., vol. 8, no. 9, 2019.

[21] M. C. B. Umanailo, N. Handayani, A. Masniati, S. H. Makatita and S. Lisaholit, "The Urbanization and Diversification of Farmland Namlea Village," Int. J. Sci. Technol. Res., vol. 8, no. 8, pp. 1049-1053, 2019.

[22] S. Kim, S. Y. Kim, and K. H. Sung, "Fortune 100 companies' Facebook strategies: Corporate ability versus social responsibility," J. Commun. Manag., 2014.

[23] S. S. Tax, D. McCutcheon, and I. F. Wilkinson, "The Service Delivery Network (SDN): A Customer-Centric Perspective of the Customer Journey," J. Serv. Res., 2013.

B. Sam et al., "Female Feminism in the Customary Island of Buru," Int. J. Sci. Technol. Res., vol. 8, no. 8, 2019. 